the aid of stainless steel producers in providing the necessary data. This assistance is acknowledged with grateful appreciation.

\section{References}

${ }^{1}$ D. C. Hilty: Relation between Chromium and Carbon in Chromium Steel Refining. Trans. AIME (1949) 185, pp. 91-95; JourNal of METALS (February 1949).

${ }^{2}$ D. C. Hilty, G. W. Healy, and W. Crafts: Metallic Oxidation in Chromium Steel Melting. Trans. AIME (1953) 197, pp. 649-653; Journal of Metals (May 1953). Abstracted by D. J. Girardi and D. C. Hilty: Oxygen in Steelmaking. Journal of Metals (July 1952) p. 705.

${ }^{3}$ W. Crafts and H. P. Rassbach: Melting Low-Carbon
Stainless Steel. Electric Furnace Steel Proceedings, AIME (1951) 9, pp. 95-104.

${ }^{4}$ D. C. Hilty: High-chromium Steel in the Acid Arc Furnace. Electric Furnace Steel Proceedings, AIME (1949) $\%$, pp. 95-104.

${ }^{5}$ J. E. Harrod: Discussion on ref. 3. Electric Furnace Steel Proceedings, AIME (1951) 9, pp. 104-106.

${ }^{6}$ B. R. Queneau and A. C. Ogan: Stainless Steel Melting Practices Have Changed. Iron Age (Dec. 4, 1952) pp. $165-169$.

${ }^{7}$ C. R. Taylor: Some Observations on the Metallurgy of Electric-furnace Melting. Electric Furnace Steel Proceedings, AIME (1950) 8, pp. 91-97.

${ }^{8}$ R. B. Shaw: Discussion on ref. 3. Electric Furnace Steel Proceedings, AIME (1951) 9, pp. 106-107.

\title{
Technical Note Thermal Conductivity of Nodular Iron
}

\section{by M. J. Sinnott}

W ITH the advent of nodular iron as an engineering material, considerable interest has been shown in developing this material for various applications. Generally the strength, hardness, or ductility are the more common properties used for design purposes but occasionally applications involving a knowledge of the thermal conductivity of the material is required. A search of the literature showed, rather surprisingly, that relatively little work has been done on this property for all types of cast iron. Insufficient data are available on thermal and electrical conductivities to develop the Weidemann-Franz ratio, or the Lorentz relationship, for estimation purposes. There are no data on nodular irons and the published data on malleable irons are quite sketchy. For these reasons the conductivity of the group of nodular irons listed in Table I were measured.

Table I. Chemical Composition of Nodular Irons

\begin{tabular}{|c|c|c|c|c|c|c|c|}
\hline Iron & Total C & $\mathbf{S i}$ & Mn & $\mathbf{s}$ & $\mathbf{P}$ & $\mathbf{N i}$ & $\mathbf{M g}$ \\
\hline $\begin{array}{l}\text { I } \\
\text { II } \\
\text { III } \\
\text { IV } \\
\text { V }\end{array}$ & $\begin{array}{l}3.57 \\
3.56 \\
3.47 \\
3.36 \\
3.33\end{array}$ & $\begin{array}{l}1.12 \\
2.27 \\
3.53 \\
4.34 \\
2.28\end{array}$ & $\begin{array}{l}0.33 \\
0.33 \\
0.29 \\
0.40 \\
0.50\end{array}$ & $\begin{array}{l}0.004 \\
0.010 \\
0.012 \\
0.010 \\
0.010\end{array}$ & $\begin{array}{l}0.035 \\
0.025 \\
0.030 \\
0.030 \\
0.055\end{array}$ & $\begin{array}{l}1.33 \\
1.30^{*} \\
1.30^{*} \\
1.23 \\
1.12\end{array}$ & $\begin{array}{l}0.06^{*} \\
0.06^{*} \\
0.06 \\
0.06 \\
0.06\end{array}$ \\
\hline
\end{tabular}

Irons I to IV were made in such a fashion as to maintain the carbon and alloy content essentially the same while varying the silicon content. Test specimens were cut from the mid-section of 4 -in. keel castings. Iron $\mathrm{V}$ is a commercial casting of nodular iron. The test specimen of this iron was cut from the center of a large cast billet $3 \times 10 \times 26$ in. All alloys were tested in the as-cast condition. A microstructural examination showed that each iron had spheroidal graphite but the size and distribution varied with the silicon content of the iron. The spheroid size decreased while the number of graphite nodules increased as the silicon content of the iron was increased. The matrix structures of each iron consisted of pearlite and ferrite with the proportions varying from predominantly pearlite in the low-silicon iron to mostly ferrite in the highsilicon iron. The commercial heat, iron $\mathrm{V}$, was predominantly pearlite probably because of its higher manganese and phosphorus content.

M. J. SINNOTT, Member AIME, is Associate Professor of Metallurgical Engineering, University of Michigan, Ann Arbor, Mich.

TN 171 E. Manuscript, May 5, 1953.
Two methods for measuring the thermal conductivity were used. The first was a modification of the techniques described by Powell and Hickman ${ }^{1}$ and Van Dusen and Shelton, ${ }^{2}$ the second method was a simpler technique described by Jakob and Hawkins. ${ }^{3}$ Since the agreement of both methods as tested on two sets of duplicate samples was excellent, the simpler experimental technique was used. The results of the measurements are given in Table II along with a summary of the microstructural constituents.

Table II. Thermal Conductivity and Microstructures of Nodular Irons

\begin{tabular}{|c|c|c|c|c|c|}
\hline Iron & $\begin{array}{l}\text { Thermal Con- } \\
\text { ductivity, Btu/ } \\
\text { Hr-Ft'-Ft//F } \\
\left(210^{\circ} \text { to } 160^{\circ} \mathrm{F}\right)\end{array}$ & $\begin{array}{l}\text { Pearl- } \\
\text { ite, } \\
\text { Pet }\end{array}$ & $\begin{array}{l}\text { Fer- } \\
\text { rite, } \\
\text { Pct }\end{array}$ & $\begin{array}{c}\text { Graph- } \\
\text { ite, } \\
\text { Pct }\end{array}$ & $\begin{array}{c}\text { Graph- } \\
\text { ite Size, } \\
\text { In. X } 100\end{array}$ \\
\hline I & 21.8 & 61 & 30 & 9 & 0.186 \\
\hline & 21.5 & 40 & 50 & 10 & 0.121 \\
\hline III & 20.9 & 35 & 55 & 9 & 0.096 \\
\hline IV & 20.3 & 5 & 85 & 10 & 0.081 \\
\hline $\mathrm{V}$ & 20.6 & 85 & 5 & 10 & 0.175 \\
\hline
\end{tabular}

These conductivity data indicate that as the percentage of silicon increases there is a corresponding decrease in the thermal conductivity even though the structure is changing from pearlitic to ferritic. Such a change in microstructure is usually accompanied by an increase in conductivity. ${ }^{4} \mathrm{~A}$ third factor involved in the behavior of these irons is the size and distribution of the graphite nodules. The relative amounts of graphite do not change greatly but the size and distribution do. Generally graphite improves the conductivity but in the present case such an effect is probably masked by the alloying effect from the silicon and its dispersion through the matrix.

The thermal conductivity of the nodular irons studied is less than that of regular foundry irons by some 10 to 30 pct and is less than that of regular malleable irons. ${ }^{4}$ The cause of the decreased conductivity is probably the more highly alloyed ferrites obtained in these irons and the changed mode of distribution of the graphite as compared to the regular foundry irons.

\section{References}

${ }^{1}$ R. W. Powell and M. J. Hickman: Journal Iron and Steel Inst. (1946) 154, No. 2, p. 99.

${ }^{2}$ M. S. Van Dusen and S. M. Shelton: U. S. Bur. Standards Journal of Research, RP668 (1934) 12, p. 429.

${ }^{3}$ M. Jakob and G. A. Hawkins: Elements of Heat Transfer and Insulation. 2nd Ed. (1950) New York. John Wiley and Sons.

${ }^{4}$ J. W. Donaldson: Journal Iron and Steel Inst. (1933) 128, No. 2, p. 255. 